\title{
THE USE OF ECONOMETRIC TOOLS FOR COST MANAGEMENT ANALYSIS
}

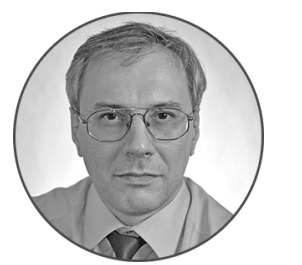

\author{
Aleksandr V. PAKHOMOV \\ AO Scientific and Production Complex Dedal (Rosatom State Atomic Energy Corporation), \\ Dubna, Moscow Oblast, Russian Federation \\ pakhomov_av@dedal.ru
}

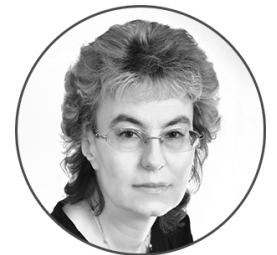

Elena A. PAKHOMOVA

Dubna State University, Dubna, Moscow Oblast, Russian Federation pakhomova.ea@phystech.edu https://orcid.org/0000-0002-3572-9614

\section{Corresponding author}

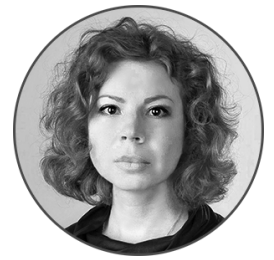

\section{Ol'ga V. ROZHKOVA}

Dubna State University, Dubna, Moscow Oblast, Russian Federation olga_r2006@mail.ru https://orcid.org/0000-0001-8406-3057

\section{Article history:}

Received 18 September 2018

Received in revised form

2 October 2018

Accepted 16 October 2018

Translated 11 February 2019

Available online 29 March 2019

JEL classification: $\mathrm{C10}, \mathrm{C80}, \mathrm{D} 20, \mathrm{~L} 22$, M40

Keywords: performance management, conditional fixed costs, conditional variable costs, multiple regression, dynamic model, spiral model

\begin{abstract}
Subject The article analyzes the cost management cycle, being a determinant of the economic result embodies in profit and better competitiveness.

Objectives Using econometric tools, we conduct an extended analysis of the cost management process by modifying and implementing components of the financial position specification technique and segregating conditionally fixed and conditionally variable costs from total costs of an entity as an element of its external environment.

Methods We relied upon financial documents of the entity producing consumer goods of limited diversity, framework of multiple regression and the financial position specification technique.

Results Having adjusted the initial technique for the specifics of the analyzable issue, we managed to expand the scope of the tools and proposed what aspects of the model should be developed so to streamline the departure from the traditional classification of economic processes into micro-, meso- and macrolevels. We analyzed the correlation of production output by brand, general fixed costs, variable costs per product unit and performance results through the break-even analysis so to make precise measurements of conditionally fixed and conditionally variable costs. The analysis revealed that the entity's operations will remain breakeven within five years to come. Making the substantive interpretation of causes and consequences of the proposed transformations and values, we take the specifics of each item into consideration, adjust tools and make assumptions for further specification in accordance with a life cycle stage, external environment, regional and macroeconomic trends, etc.

Conclusions and Relevance As the computations show, costs can be segregated, with modern information and computing tools being able to ensure not only an operational and practicable algorithm, but also the sufficient quality of analytical finding, which would allow to make and implement further managerial decisions.
\end{abstract}

๑) Publishing house FINANCE and CREDIT, 2018

The editor-in-charge of this article was Irina M. Vechkanova

Authorized translation by Irina M. Vechkanova

Please cite this article as: Pakhomov A.V., Pakhomova E.A., Rozhkova O.V. The Use of Econometric Tools for Cost Management Analysis.

Digest Finance, 2019, vol. 24, iss. 1, pp. 21-33.

https://doi.org/10.24891/df.24.1.21 


\section{Introduction}

As the analysis of the existing socio-economic processes shows, new conditions induce the transformation of customary relationships. Although the economic phenomenon of costs has been extensively covered in the literature, being of very practical nature, it actually implies very complex relationships and terminological collisions. The terminological string cost - costs - expenditures is interpreted with methodological discrepancies, thus influencing the monitoring of respective indicators, financial result formation approaches and their recognition in financial statements.

In the Russian practice of management accounting, the above terms are applicable, though they are not synonyms. There is no unanimous opinion which of them (cost, costs or expenditures) has the broadest meaning. Therefore, terminological discrepancies distort the analysis of the respective item.

As part of the general approach, costs are systematized by purpose and objective of economic analysis, type, element, article, agent, accrual methods, cost centers, etc.

Cost of products is a comprehensive resultant metric indicating the use of corporate resources and other aspects of its financial and economic performance. Therefore, it is important to analyze the conditions for costing and effect of various factors ${ }^{1}$ to evaluate the corporate position. In the contemporary economic theories and practices, the cost of product means current costs incurred by the entity in the monetary form for direct operational functions, i.e. production and distribution [1]. The cost is a subset of the cost management set in relation to a respective business entity. The cost is mainly managed so as to create the cost management system ${ }^{2}$, which requires in the more and more unpredictable environment to comply

${ }^{\dagger}$ For the source article, please refer to: Пахомов А.В., Пахомова E.A., Рожкова О.В. Применение эконометрического инструментария для анализа процесса управления затратами // Экономический анализ: теория и практика. 2018. Т. 17. № 12. С. 1459-1477.

URL: https://doi.org/10.24891/ea.17.12.1459

${ }^{1}$ Rozhkova O.V., Franstuzova E.V. [Factor analysis for the evaluation of corporate financial-economic analysys]. Sbornik nauchnykh trudov Sworld, 2017, vol. 4, no. 46, pp. 16-20. (In Russ.)

${ }^{2}$ Chernysheva Yu.G., Kochergin A.L. Kompleksnyi ekonomicheskii analiz khozyaistvennoi deyatel'nosti [Comprehensive economic analysis of business operations]. Roston-on-Don, Feniks Publ., 2007, 443 p. with management principles for the correlation of resources, costs, goals and results.

Direct costing (marginal costing, variable costing ${ }^{3}$ ) turns up to be one of the most precise approaches to measuring the cost. A lot of researches focus on this approach to study its tole in managerial decision making concerning the product mix, production volume, breakeven point, pricing, marketing strategy at different phases of the corporate life cycle.

The above system requires to account for costs classified into direct (immediately incurred to manufacture a production unit) and indirect, which are allocated by type of products through a certain technique (in the case of an entity making more than one type of products) and attributed to financial result [2].

The methodological framework of the so called direct costing system is the segregation of all costs, which is understood with a certain approximation, into variable VC (production and non-production depending on business performance, including changes in production output and uneven dynamics ${ }^{4}$, and fixed $F C$, that do not depend on the production output (or depend insignificantly) ${ }^{5}$. Mostly, direct costs are variable, while indirect ones can be both variable and fixed.

In the case of most managerial decisions, it is the variable element of the cost ${ }^{6}$ of production out that is important to know, i.e. Cost $\equiv T V C$, where TVC stands for Total Variable Costs, or general variable costs. The fact that the cost measurement requires a permanent component to be included is a disputable issue, which helps understand the full cost of finished products or construction in progress (CIP), valuation of inventories, etc. However, this entails risks of ineffective control and subsequent distortion of results (for example, profitability, etc.).

\footnotetext{
${ }^{3}$ Brown G. Introduction to Costs Accounting: Methods and Techniques. URL: http://www.globusz.com/ebooks/Costing

${ }^{4}$ Ekonomicheskaya teoriya [Economic theory]. Ed. by A.I. Arkhipov, S.S. Il'ina. Moscow, Velbi, Prospekt Publ., 2010, 608 p.

${ }^{5}$ Kerimov V.E. Uchet zatrat, kal'kulirovanie i byudzhetirovanie v otdel'nykh otraslyakh proizvodstvennoi sfery [Cost accounting, costing and budgeting in certain manufacturing sectors]. Moscow, Dashkov i K Publ., $2008,476 \mathrm{p}$.

${ }^{6}$ Scone T. Upravlencheskii uchet: kak ego ispol'zovat' dlya kontrolya biznesa [Management Accounting]. Moscow, Audit, YUNITI Publ., 1997, $179 \mathrm{p}$.
} 


\section{The Method for Analytical Segregation of Conditionally Fixed and Conditionally Variable Costs and Its Modification}

Measuring the percentage of indirect costs in total corporate costs is the most difficult part of the practical segregation of conditionally fixed and conditionally variable costs in total costs. However, an analytical chart of approximated linear dependency of the cost on production output [3], which is an option to model economic dependencies through linear equations for analysis and forecasting, helps attribute then to a certain type of activity or product, adjust the production output and amend pricing policy.

The method consists in the following steps:

- plotting the cost to show the dependency on the core production volume;

- setting the linear trend of the cost;

- formulating the trend line equation as a line $y=a+b x$ and segregation of conditionally fixed and conditionally variable costs $b$;

- analyzing the results, segregation of variable components making the cost of products.

We analyze an entity which is one of the largest manufacturers of industrial rubber products in Russia and the CIS and a long-standing strategic partner of the leading enterprises operating in defense, mining, coal production, transport, food production, machine building, metallurgy and agriculture.

Consider using the proposed method (or the need to modify it) in an entity from another industry (consumer products, namely makeup manufacturing). Despite the recent geopolitical and economic developments, the consumer demand for new cosmetic products continues to increase, though being slower, but cosmetic brands keep their development trend, thus making the Russian cosmetic market one of the most attractive and rapidly growing ones worldwide. Multinationals still remain the leaders in the industry, with about ten companies holding 80 percent of the market, though all the segments feature not only foreign, but also the Russian manufacturers ${ }^{7}$.

The analyzable entity herein has the following characteristics:

\footnotetext{
${ }^{7}$ Overview of Russia's cosmetics market. URL: https://adindex.ru/specprojects/markets3/cosmetics-1.phtml (In Russ.)
}

- new independent industrial enterprise operating as part of the existing corporate system and taking over the production of items which were previously manufactured by third party companies, including foreign ones, on a contractual basis;

- substantial investment;

- involvement of resources from almost all functional areas of the enterprise initiating the project (marketing, finance, logistics, etc.);

- ensuring the overall business compliance with the international financial reporting standards and subsequent certification of the quality management system under GOST R ISO 9000.

First, there is a considerable difference between total costs and cost when an innovative product or service if created and launched. Second, such projects are often innovative from different viewpoints since innovations reshape the governance mechanism and competitiveness area $^{8}$. Such an enterprise mainly strives for import substitution, i.e. alleviating the dependence of the product on foreign manufacturers and reducing the production and logistic leverage, thus boosting the competitiveness.

Our reasoning is based on the following steps.

Step 1. At Step 1, we determine the composition, characteristics and statistical values of relevant economic variables for a five years' period: two trademarks $T M_{1}$ and $T M_{2}$ and production output respectively $Q_{1}$ and $Q_{2}$, with total production output $Q$; the list of fixed costs $F C$ by item; general variable costs for $T M_{1}-T V C_{1}$ and for $T M_{2}-T V C_{2}$, and total variable costs TVC and variable costs per product unit VC.

The analysis of variables was guided by the following assumptions:

- parameters are viewed as constant values (though all costs tend to increase in the long run);

- demand for such products rises, with structural market development missing;

- product mix and selling price are permanent;

- production volume is kept within a relevant range, being the only factor influencing production costs;

\footnotetext{
${ }^{8}$ Pakhomova E.A., Rozhkova O.V. [Product line planning aspects as part of the corporate planning system]. Strategicheskoe planirovanie i razvitie predpriyatii. T. 3: materialy XVII Vserossiiskogo simpoziuma [Proc. Sci. Conf. Strategic Planning and Development of Enterprises. Vol. 3]. Moscow, CEMI RAS Publ., 2016, pp. 126-129. (In Russ.)
} 
- production output and sales as of the beginning and end of the analyzable period depend on sales of the project initiating company's product, being the only factor influencing expenses and income;

- financial, human resources and production capacities are strictly stipulated, limited, being unchangeable;

- credit, fiscal and other factors are not considered.

Step 2. We formalize input data to comply with the economic theory ${ }^{9}$ :

$T C=F C+V C \cdot Q$,

where $T C$ is total costs of an entity;

$F C$ is fixed costs;

$V C$ is variable costs per product unit;

$Q$ is production output.

Relying upon input data (business plan for business incorporation, budgeted income and expenses, statement of profit and loss, balance sheet, estimated and reported cost of products), we compute variable costs per product unit for $T M_{1}$ and $T M_{2}$ via MS Excel spreadsheet:

$$
V C_{1}=\frac{T V C_{1}}{Q_{1}} \text { and } V C_{2}=\frac{T V C_{2}}{Q_{2}} \text {. }
$$

The most intensive controversy arose around the assumption that, according to the input data, in the first year of corporate operations, variable costs per product unit depend on the production output in the short run, i.e. $V C=V C(Q)$, while total variable costs TVC per product unit should remain unchanged. This may possibly be due to the specifics of the task. During the start-up phase and testing of production launch conditions, commissioning work, production output adjustment, the entity often changes suppliers, thus causing alterations in the cost, standards and characteristics of raw materials and suppliers, etc.

We measure $F C$ and $T C$ per each TM by apportionment. Therefore,

$$
\begin{aligned}
& F C_{1}=\frac{Q_{1}}{Q_{1}+Q_{2}} F C ; \\
& F C_{2}=\frac{Q_{2}}{Q_{1}+Q_{2}} F C ;
\end{aligned}
$$

\footnotetext{
${ }^{9}$ Palamarchuk A.S. [Assessment and rationale for managerial decisions]. Spravochnik ekonomista = Economist's Guide, 2012, no. 5, pp. 40-51. (In Russ.)
}

$$
\begin{aligned}
& T C_{1}=\frac{Q_{1}}{Q_{1}+Q_{2}} T C \\
& T C_{2}=\frac{Q_{2}}{Q_{1}+Q_{2}} T C .
\end{aligned}
$$

Step 3. We express the revealed relationship mathematically and formulate the boundaries of the model. All values of the economic-mathematical models represent both variables and independent parameters [4]. We equate them with certain performance indicators and particular figures. Afterwards we identify whether there is a functional dependency among general variable costs (dependent variable) TVC and production output as for general $Q$ and $Q_{1}, Q_{2}$ in particular (independent variables):

$$
\begin{aligned}
& T V C=T V C(Q) ; \\
& T V C_{1}=T V C_{1}\left(Q_{1}\right) ; \\
& T V C_{2}=T V C_{2}\left(Q_{2}\right) .
\end{aligned}
$$

To make the regression equation with meaningful coefficients and estimates, we follow step-by-step methods for correlation and regression analysis and STATISTICS software application.

Please refer to the research indicated herein [5] for information about using econometric methods to verify socio-economic relationships and probability of mutual effect by evaluating the elasticity. In this case, we confine ourselves to the given equations:

TVC = -52,549.8+0.7Q;

$T V C_{1}=-4,210.82-1.11 Q_{1}$;

$T V C_{2}=-56,914.6+0.7 Q_{2}$.

The above computations allow us to conclude that the $a$-offset is negative. However, the coefficient provides a predicable $y$ if $x=0$ (in case of the given equations if production output is zero) and shall be interpreted only if it has meaningful economic substance. If the absolute term of equation $a$ is negative, it may mean that the domain of $y$ does not include zero value of $x$ and approximate values. Although it is possible to assess the minimum value of factor $x$, which would ensure the lowest positive value of $y^{10}$, it appears to be impossible to verify statistical hypotheses with respect to all values of variables in the population and identify all random components influencing independent variable $y$. In the situation, the value of explanatory variable $x$ on the

\footnotetext{
${ }^{10}$ Eliseeva I.I., Yuzbashev M.M. Obshchaya teoriya statistiki [General theory of statistics]. Moscow, Finansy i Statistika Publ., 2004, 656 p.
} 
sample is far from zero. Hence, the exclusion of the negative fixed term will distort the assessment and result in the incorrect $t$-test.

The equations also constitute an interim step of the analysis and provide an analytical description of available economic data within the given range of parameters. Hence the fact that the regression coefficient is not zero is important, rather than its sign. The correlation of analyzable indicators as determination coefficient $R^{2}$ ranging within 0.9778 to 0.9905 matters in evaluating the independence. This means that the variance of factor attributes ${ }^{11}$ prevail as compared with the rest factors, which the model does not accommodate to, influencing the resultant indicator. In all the three equations, there is a strong functional and statistically meaningful correlation of the indicators under a 99-percent confidence level. As per Ftest, the equations are also reliable.

The same approach works to identify the existence of a functional correlation of total variable costs (dependent variables) TVC and production output (independent variable) with respect to certain brands $Q_{1}, Q_{2}$. We detected the positive correlation of TVC and production output $T M_{2}\left(Q_{2}\right)$, while the negative correlation is captured in the case of TVC and production output $T M_{1}\left(Q_{1}\right)$. This may be due to an insignificant share of the brand in total production output (from 5 to 7 percent within the span of four yeas and subsequent phaseout). Presented graphically, the correlation of TVC and Q1 approximates 0 , thus debunking the hypothesis of TVC = $\operatorname{TVC}\left(Q_{1}\right)$

Step 4. Considering the data obtained at Step 2 and functional correlation identified at Step 3, we specify the equation $y=a+b x$ in terms of total costs TC and find conditionally fixed costs $a$ and conditionally variable costs $b$. Whereas $T V C_{1}=T V C_{1}\left(Q_{1}\right)$, but $T V C \neq$ $\operatorname{TVC}\left(Q_{1}\right)$,

and

$T V C_{2}=T V C_{2}\left(Q_{2}\right)$ and $T V C=T V C\left(Q_{2}\right)$, then we use the formulas $T C_{1}=\frac{Q_{1}}{Q_{1}+Q_{2}} T C$ and (like $T C_{2}$ ) figure out that the result of regression equations concerning conditionally fixed costs $a$ is assigned an incorrect sign in terms of economic theory. Therefore, such a regression equation cannot, as a rule, be of genuine sense and should be analyzed and adjusted.

\footnotetext{
${ }^{11}$ Aivazyan S.A., Mkhitaryan V.S. Teoriya veroyatnostei i prikladnaya statistika. T. 1 [Probability theory and applied statistics. Vol. 1]. Moscow, YUNITI Dana Publ., 2004, 656 p.
}

Taking a more detailed view of the above equations, we arrive at $\frac{Q_{1}}{Q_{1}+Q_{2}} T C=a+a_{1} Q_{1}+b_{1} Q_{1}^{2}$ (likewise for $Q_{2}$ and $Q)$, which corresponds with the following equation $y=a+b x+c x^{2}$.

Step 5. We evaluate the resultant regressions, check the model for adequacy, clerical accuracy and compliance with the existing economic phenomena. To begin with, we compare the result of Step 4 in equations like $y=a+b x$ with input data. As for the dependency of $T C$ on $Q$, the equation is expressed as $T C=-41,158.9+$ $0.7 Q$ provided the determination coefficient is 0.9896 , thus evidencing the high quality of regression in general. The statistical significance of the determination coefficient is corroborated with the correspondingly high $F$-test. Hence the regression equation includes at least one explanatory vaiable, which is proved with high $t$-test of the coefficients ${ }^{12}$.

As for conditionally fixed costs $(-41,158.9$ and 36,944$)$ and conditionally variable costs ( 0.7 and 0.5$)$, results insignificantly differ from input data. Therefore, the given significance level allows to use the equation with the computed coefficients, but also adjust so as to get an adequate and more accurate result, since the coefficient considerably depend on the scale rule gauging the variables. A similar decision was make concerning $T M_{2}$, while the coefficients may not be improved in the case of $T M_{1}$, since it accounts for a small share in total volume. We assume that the negative sign of coefficient $a$ can be economically interpreted as an impact of those fixed expenses incurred during several months preceding the production launch. Statistically, it can be construed as the inclusion of negative figured into the confidence interval. In the mean time, the expenses are so insignificant to cause the exclusion of the absolute term.

In all equations expressed as $y=a+b x+c x^{2}$ and having correct signs in terms of the economic theory, there is a positive correlation of three indicators $\left(T C_{i}, Q_{i}\right.$ and $\left.Q_{i}^{2}\right)$. In particular, the regression equation is expressed as follows for the same indicators $T C$ and $Q$ :

$T C=11,515.74+0.43 Q+4.01 \cdot 10^{-7} Q_{2}$

with the determination coefficient $R^{2}$ equaling 0.9936 , and the coefficient value $4.01 \cdot 10^{-7}$ is insignificant.

\footnotetext{
${ }^{12}$ Borodich S.A. Ekonometrika [Econometrics]. Minsk, Novoe znanie Publ., 2001, 408 p.
} 
Having checked the accuracy of the regression analysis, we concluded that thee are statistical grounds to consider the resultant equation satisfactory and appropriate for purposes of forecasting and analysis and qualify the results as sufficiently reliable.

Comparing the resultant conditionally variable costs (0.43) and conditionally fixed costs $(11,515.74)$ with input data ( 0.5 and 13,918 respectively), we state that the equation is not only correctly expressed, but its results also almost meet the given conditions. Hence, using the quadratic terms, we build equations with statistical characteristics and economic substance excelling the previous ones.

This may be due to the fact that the inclusion of regression generally improves the model because any new attribute makes it more informative, contributing to the variance of the dependent variable. Moreover, this often stems from the economic reasonableness of including closely related factors. However, the close relation of explanatory variables may prevent the graphic presentation and cause the multicollinearity and more complicated selection of the best regression equation ${ }^{13}$.

Step 6. We substantiate aspects for further improvement of the model and its information and mathematical framework. The step reveals the dynamic substance of the regression analysis. Let us reassume the verification of an alternative hypothesis stating than the cost is not equal to TVC, i.e. exceeding TVC. Regression equations like $y=a+b x$, where $x=T V C_{i}$ are expressed as follows for $T M_{1}$ and $T M_{2}$ :

Cost $_{1}=7,726.39+3.04$ TVC $_{1}$;

Cost $_{2}=544,258.29+12.16 T_{V C}$.

Whereas Total Variable Costs $T V C_{i}=\left(\right.$ Cost $\left._{i}-a_{i}\right) / b_{i}$ variable costs per product unit $V C_{i}$ can be measured with the formula, such as

$V C_{i}=T V C_{i} / Q_{i}=\left[\left(\operatorname{Cost}_{i}-a_{i}\right) / b_{i}\right] / Q_{i}$.

Signs of the regression coefficients are correct in terms of substance. The determination coefficient $R_{2}$ amounted to 0.99 and 0.78 respectively, signifying the strong and moderate correlation when the significance level is below 1 percent and the significance of the parameters is at least 5-7 percent.

\footnotetext{
${ }^{13}$ Ekonometrika [Econometrics]. Ed. by V.S. Mkhitaryan. Moscow, Prospekt Publ., 2011, 384 p.
}

Therefore, such verification helps identify those parameters, which should be specified within certain numerical boundaries [6], and reduce computational steps with respect to a specific equation. Varying the values deliberately and evaluating them at each step makes quite an arduous process, but it ultimately allows to choose the best-fit one, thus improving the model mathematically. If the time factor is taken into consideration, such tasks require to simply divide the entire time interval $\left[t_{0}, T\right]$ and solve a number of tasks for each step $(t+1)$, which out of the scope of this research.

The technique seems suitable because it helps choose the right step to evaluate the model's parameters at each step of the analysis. For example, measured through apportionment at Step 2, indicators of fixed costs $F C$ can be viewed by selecting an appropriate step $\Delta Q:$

$$
\begin{aligned}
& F C_{1}^{\prime}=\frac{Q_{1}-\Delta Q}{Q_{1}+Q_{2}} F C ; \\
& F C_{2}^{\prime}=\frac{Q_{2}-\Delta Q}{Q_{1}+Q_{2}} F C .
\end{aligned}
$$

The steps described herein and previously can be outlined in Fig. 1.

It is quite logical and reasonable to economically develop the model in order to find the break-even point and measure the operational leverage, since it requires to analyze the dependence of performance results (products or certain type of products, trademark) on sales, production and costs [7], which are studied herein as fixed and variable categories. Making estimates for the coming five years, we suppose that the entity will remain break-even.

It is noteworthy that the varying calculus streamlines the analysis and forecast of changes in a bunch of indicators not only for purposes of the corporate internal policies at different stages of its life cycle, equalizing the profitability and risk, but also for comparing its market position, alleviating the impact of the negative market environment, and industry-specific benchmarking. Assuming that total costs equal, risks are lower (that is, business is more sustainable) if variable costs exceed fixed ones.

Step 7. Analysis of results and their application. At the final step of the modeling cycle, it is necessary to evaluate not only the correctness and completeness of results from perspectives of the economic theory, but 
also interpret them in terms of substance with respect to a real-life object, which is to be described with the invented model, and provide hands-on recommendations.

Results of each cycle are valuable per se. However, if they are viewed through new conditions and specified through functional dependencies, first, they will help rectify the model's drawbacks at the following steps (including a choice of a more appropriate mathematical framework and avoidance of inherent methodological errors). Second, they spotlight new areas for research into objects, environments, projects and processes, being the most conspicuous and high-profile aspects of economic phenomena and systems and actually representing all their possible types [8].

The well elaborated model can be used to reveal the correlation and internal mechanisms of processes under study. If the product mix is scarce, the task does not require special models, high qualification of specialists, being quite applicable to goods of stable demand. When the entity offers a wide array of products, for example, operating in the consumer goods market, econometric methods should become a reasonable and effective step. For example, mathematical statistics, linear and nonlinear programming, games theory, etc. However, what complicates the modeling is the collection of relevant, sufficient and appropriate information [9]. Hence it is worth mentioning that better and more precise planning may boost some costs, raising the issue of marginal utility of doing so and ultimately cost effectiveness (Fig. 2).

Fig. 3 depicts the cyclical nature of such research, moving from the economic theory and business practice to econometric modeling, analysis of internal and external processes and, consequently, suggestions on the improvement of the theory and economic policy.

As for the microlevel, such a cyclical model can be quite precisely described and convenient because it gives a concise view of the data, to the advantage of descriptive models [10]. Descriptive models serve for managing a process, without requiring to study its mechanism.

However, considering an entity as part of its external surroundings, the cycle can be examined in close connection to structural modifications of upper-level socio-economic systems, thus enriching the traditional knowledge of economic hierarchical systems (Fig. 4) and creating new subjects for scientific analysis.
The approach involves several models, which we have built, reflects a correlation of indicators over time and describes cooperation aspects as part of real economic processes.

\section{Transformability of Microdescriptions into Macromodels}

Macro-, meso- and microeconomic levels are connected by economic elements viewed in terms of their group interactions. Thus, the most important function is to set up mechanisms for managing the agents at different hierarchical levels (microelevel of certain entities; mesolevel that is interim and intended for groups to unite economic regions; macrolevel including the nation and society as a whole [11]) by assessing functional parameters through economic-mathematical modeling [12]. Such units are mainly formed to implement their competence on the basis of measurable results (at the corporate level, the innovative production is meant inter alia) and seize opportunities of the integration through the cost reduction [13]. It is one of the most important objectives of most Russian enterprises. Costs increase as raw materials and supplies appreciate and tariffs, interest rates and so on are raised. Whereas there is no effective technique of goal achievement, provided the entity uses resources reasonably and responsibly, the formation of integral and coherent economic systems, which drive the intensive reproduction and development in the long-run, lags, notwithstanding any adverse effects that may arise.

The analysis of supply and demand, product mix planning, cost management and other measures for detecting what influences the pricing [14] as one of the competitiveness drivers become the background for joint projects (Fig. 5) and implementation of the national strategic initiative specifically as part of the mesoeconomic space [15], which unite local and industrial management, sets regional and macroeconomic trends needed for spurring the economic growth.

The models and patterns we study herein pertain to the overall system description. They are supposed to be attributed to the mesoeconomic level and included into the consolidated economic models. The combined approach accommodates for macro- and mesoeconomic processes.

The presented spiral model (Fig. 6) puts a special focus on risks. For example, a lack of professional talent, ignorance of project management techniques, lack of 
information on the external environment, statistical data, etc.

\section{Conclusions}

The economic science should dwell upon realistic assumptions and provide tools for understanding and clarifying the economic environment ${ }^{14}$. V.L. Makarov, director of the Central Economics and Mathematics Institute of the Russian Academy of Sciences, confirms that contemporary economics rests on three pillars, i.e. macroeconomics, microeconomics and econometrics. The gap among the three pillars should be as narrow as possible. It turns to be rather complicated since the Russian enterprises lack scientifically proven methods for decision making. Therefore, it is important to develop the respective tools. We should note that econometric results should simply serve as the rationale for managerial decisions at any level.

Furthermore, the complexity of economic processes influences the possibility of setting illustrative and practicable mathematical models for a long-term time span, in particular. It also makes it difficult to test them for adequacy and compliance with the real economic situation. Therefore, before deciding which aspects of the model should be improved, numerical results and substantive conclusions should be primarily found and analyzed for any deviation from the reality so as to identify any drawbacks of the model and the task.

As a result of the analysis, only some equations were found to concord with the economic theory, have appropriate signs or values, which can be qualified as indicia of multicollinearity. However, even if multicollinearity is not found, some coefficients of regressors can be insignificant. The multiple regression framework gets difficult to use when some multicollinearity factors are in place, i.e. when more than two factors have a linear correlation, that is, they reciprocally influence one another. Correspondingly, multicollinearity is preferably tackled with the method which does not cause any changes in regressors and has no impact on their composition ${ }^{15}$.

However, after the tools were updated through the quadratic term $c$, which specifies the effect $Q_{2}$, we arrived at adequate values of conditionally fixed costs

\footnotetext{
${ }^{14}$ Ekonometrika [Econometrics]. Ed. by I.I. Eliseeva. Moscow, Yurait Publ., 2014, 449 p.

${ }^{15}$ Gladilin A.V., Gerasimov A.N., Gromov E.I. Ekonometrika [Econometrics]. Moscow, KnoRus Publ., 2017, 228 p.
}

and conditionally variable costs that are close to input data, while coefficients of the technical axis $Q_{2}$, which were almost zero, corroborated the independence of variables per product unit on variable costs in direct proportion to the output. There is no multicollinearity in the case of such an adjustment, since the same factor is taken into consideration and $Q_{2}$ is a technical axis. The resultant regression equations are of high practical value. It is noteworthy that we disregard time and some other factors due to the specifics of the corporate life cycle stage. That is, investment has already been made, requiring just to decide on the product mix and production volume.

Is it reasonable to earmark costs this way? The answer depends on the effectiveness of their management and control. This requires to monitor the security margin of corporate performance and adjust threshold values of production and costs at each point of time. Ongoing monitoring of relevant information and its analysis transformed into the practice of data mining ${ }^{16}$, pursuing to find any deviation and trends using up-to-date computational technologies [16], which have become so current for the recent years as a new form of the information approach.

Whereas the said indicia may be missing in business operations, the results are rather conditional, giving just an overall view. They should be detailed in accordance with a life cycle stage, external environment, regional and macroeconomic trends, etc.

Difficulties in interpreting the factor indicia may be considered as drawbacks of the proposed technique since they to an extent complicate its practical use. In our opinion, it is due to the fact that the indicator varies considerable since the model comprises yet unrecognized factors, sample size and immediate substance of the analyzable task ${ }^{17}$. Cost management has multiple aspects, necessitating further research and new approaches supplementing the one proposed herein, which would synthesize principles of performance by objectives. Departing from the traditional segregation of economic processes by level (mecro-, meso- and macro) and analyzing them in their totality will give a new impetus to similar studies.

\footnotetext{
${ }^{16}$ Knowledge Discovery Through Data Mining: What Is Knowledge Discovery? Tandem Computers Inc., 1996.

${ }^{17}$ Magnus Ya.R., Katyshev P.K., Peresetskii A.A. Ekonometrika [Econometrics]. Moscow, Delo Publ., 2004, 576 p.
} 


\section{Figure 1}

The cyclical modified technique for multilevel sequential analysis of cost management

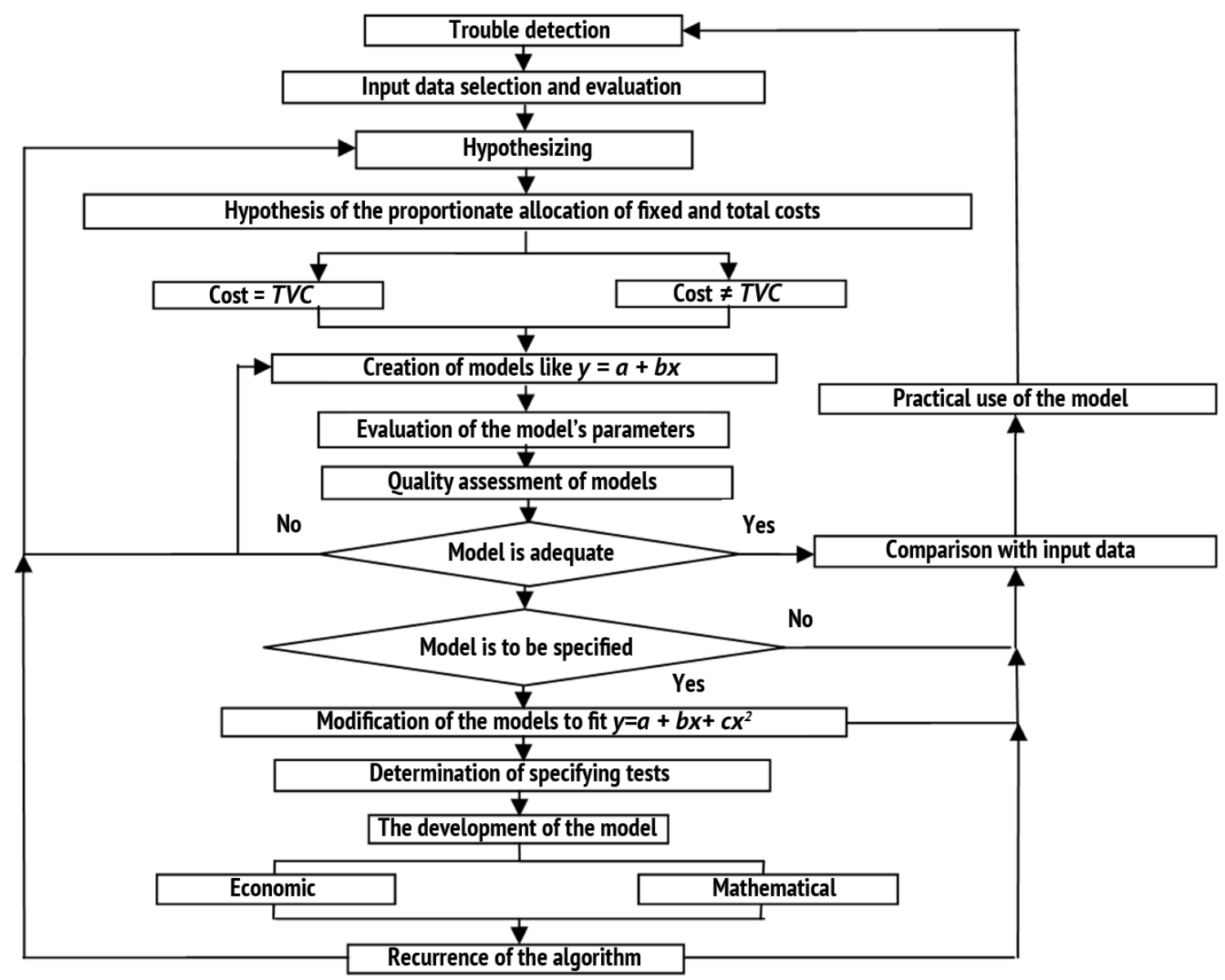

Source:Authoring 
Figure 2

The ideology behind a choice of evaluation techniques

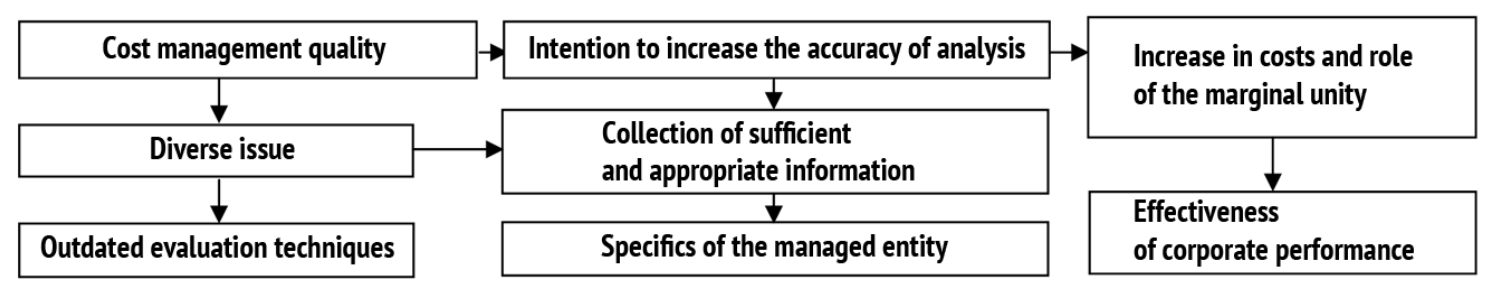

Source:Authoring

Figure 3

The cyclical nature of research

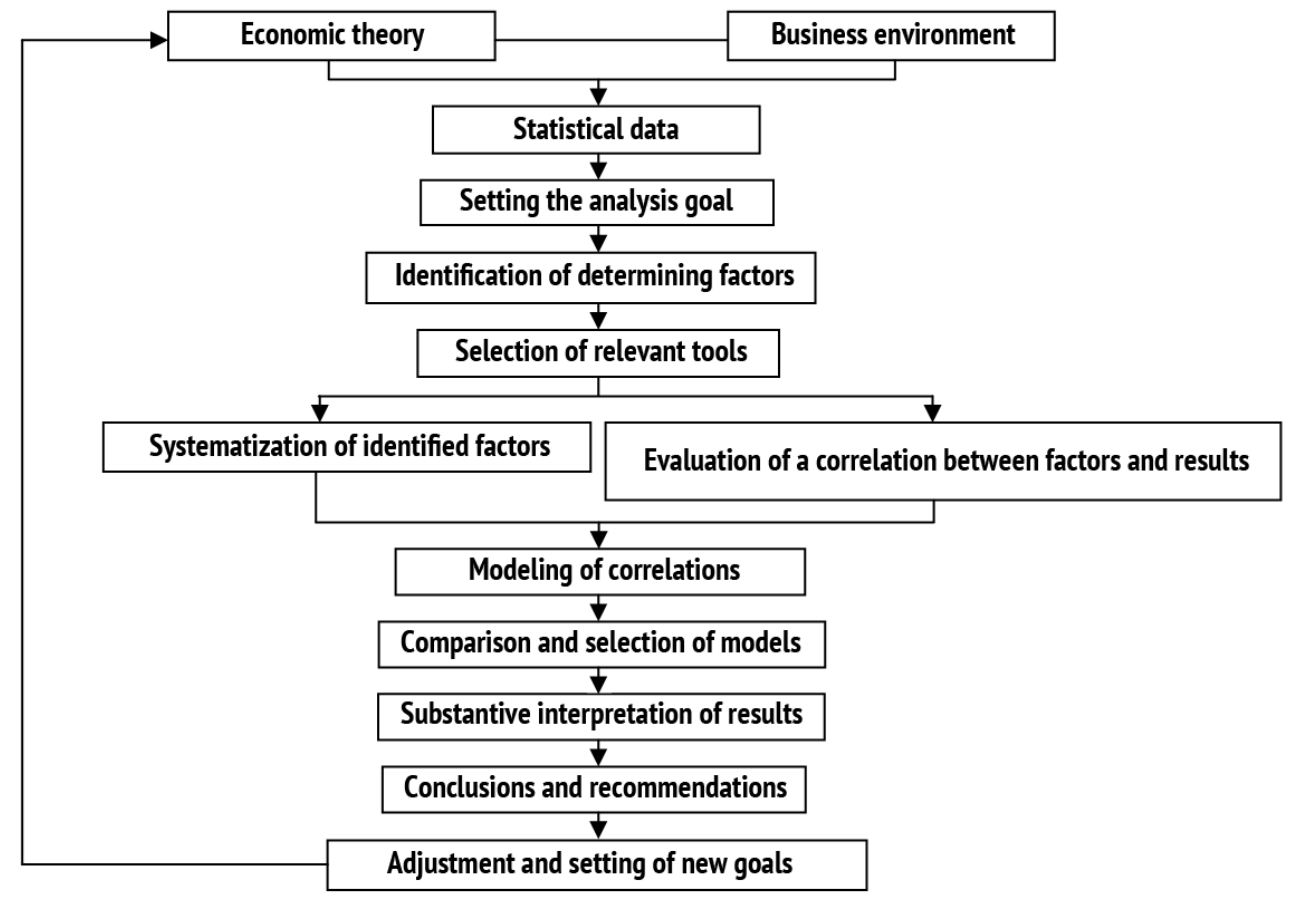

Source:Authoring

Please cite this article as: Pakhomov A.V., Pakhomova E.A., Rozhkova O.V. The Use of Econometric Tools for Cost Management Analysis. 


\section{Figure 4}

The trend map of economic levels and correlation of models

(3) Model to study a correlation of retail, mortgage and housing lending volumes and some socio-economic indicators

(3) Correlation and regression analysis
$\begin{aligned} & \text { (5) Model to forecast the employment through } \\ & \text { demand and supply in the regional labor market } \\ & \text { of deviation } \\ & \text { of a manufacturing enterprise by non-numerical } \\ & \text { statistical methods }\end{aligned}$
(4) Model to differentiate regions by socio-economic
profile by the cluster analysis method

Source:Authoring

\section{Figure 5}

The structural map of typical interaction issues and approaches to addressing them

\begin{tabular}{|l|l|}
\hline $\begin{array}{l}\text { Budget control and different } \\
\text { budgetary controur } \\
\text { of operational } \\
\text { and strategic interests }\end{array}$ \\
\begin{tabular}{|l|l|} 
Multiple information \\
various analysis techniques
\end{tabular} \\
\hline Alteration of the existing network \\
of interactions and practices
\end{tabular}

Source:Authoring

Please cite this article as: Pakhomov A.V., Pakhomova E.A., Rozhkova O.V. The Use of Econometric Tools for Cost Management Analysis. 


\section{Figure 6}

The graphical presentation of the spiral method for innovative production

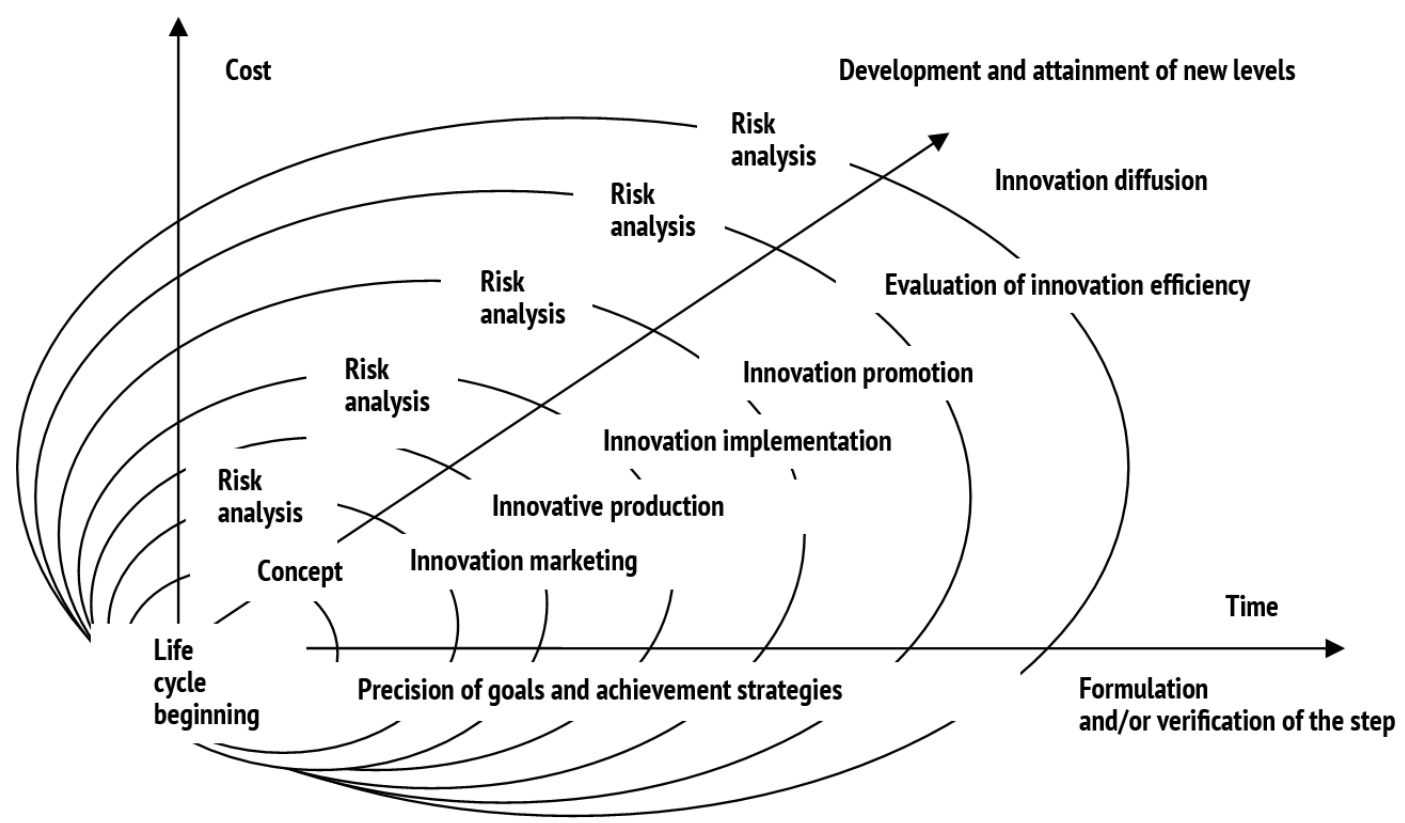

Source:Authoring

\section{Acknowledgments}

The article was supported by the Russian Foundation for Basic Research as part of project № 17-06-00301, Organizational and Economic Mechanism to Manage Innovation in the Consumer Goods Market: Methods, Models, and Tools.

\section{References}

1. Ponomarenko Yu. [Cost calculation in financial and tax accounting]. Nalogovyi vestnik, 2009, no. 2, pp. 34-36. (In Russ.)

2. Glazov M.M., Chernikova S.Yu. Upravlenie zatratami: novye podkhody: monografiya [Cost management: New approaches: a monograph]. St. Petersburg, Russian State Hydrometeorological University Publ., 2009, 169 p.

3. Pakhomov A.V. [Some methods of evaluating financial and economic state of an enterprise]. Ekonomika $i$ matematicheskie metody = Economics and Mathematical Methods, 2002, vol. 38, no. 1, pp. 57-65. (In Russ.)

4. Vilkas I.E., Maiminas E.Z. Resheniya: teoriya, informatsiya, modelirovanie [Solutions: Theory, information, modeling]. Moscow, Radio i svyaz' Publ., 1981, 328 p.

5. Pakhomov A.V., Pakhomova E.A., Rozhkova O.V. [Differentiating the Russian regions through an econometric analysis by socio-economic indicators influencing the consumer demand]. Natsional'nye interesy: prioritety i bezopasnost' = National Interests: Priorities and Security, 2017, vol. 13, iss. 12, pp. $2200-2217$. URL: https://doi.org/10.24891/ni.13.12.2200 (In Russ.)

6. Astrakhantsev G.P. [Iterative correction of eigenvalues]. Vychislitel'naya matematika i matematicheskaya fizika = Computational Mathematics and Mathematical Physics, 1976, vol. 16, no. 1, pp. 131-139.

URL: http://www.mathnet.ru/php/archive.phtml?wshow=paper\&jrnid=zvmmf\&paperid=6137\&option_lang=rus (In Russ.) 
7. Van Horne J., Wachowicz J. Osnovy finansovogo menedzhmenta [Fundamentals of Financial Management]. Moscow, Vil'yams Publ., 2008, 1232 p.

8. Kleiner G.B. Razvitie teorii ekonomicheskikh sistem i ee primenenie v korporativnom i strategicheskom upravlenii [Development of the theory of economic systems and its application in corporate and strategic management]. Moscow, CEMI RAS Publ., 2010, 48 p.

9. Manyika J., Chui M., Brown B. et al. Big Data: The Next Frontier for Innovation, Competition, and Productivity. McKinsey Global Institute, 2011.

10. Glinskii B.A. et al. Modelirovanie kak metod nauchnogo issledovaniya (gnoseologicheskii analiz) [Modeling as a method of research (epistemological analysis)]. Minsk, MSU Publ., 1965, 248 p.

11. Kirdina S.G. [Methodological institutionalism and the importance of meso-level of social analysis]. Sotsiologicheskie issledovaniya = Sociological Studies, 2015, no. 12, pp. 51-59. URL: http://socis.isras.ru/article/5867

12. Kosachev Yu.V. Ekonomiko-matematicheskie modeli effektivnosti finansovo-promyshlennykh struktur [Economic and mathematical models of the efficiency of financial and industrial structures]. Moscow, Logos Publ., 2004, $248 \mathrm{p}$.

13. Kleiner G.B., Tambovtsev V.L., Kachalov R.M. Predpriyatie v nestabil'noi ekonomicheskoi srede: rynki, strategii, bezopasnost' [An enterprise in an unstable economic environment: Markets, strategies, safety]. Moscow, Ekonomika Publ., 1997, 288 p.

14. Marn M.V. et al. Tsenovoe preimushchestvo [The Price Advantage]. Moscow, Al'pina Biznes Buks Publ., 2004,317 p.

15. Gel'vanovskii M., Zhukovskaya V., Trofimova I. [Competitiveness in micro-, meso- and macro-level measurements]. Rossiiskii ekonomicheskii zhurnal = Russian Economic Journal, 2008, no. 3, pp. 67-77. (In Russ.)

16. Bruskin S.N. [Methods and tools of advanced business analytics for corporate information analytical systems in the digital transformation era]. Sovremennye informatsionnye tekhnologii i IT-obrazovanie, 2016, vol. 12, no. 31, pp. 234-239. URL: https://cyberleninka.ru/article/n/metody-i-instrumenty-prodvinutoy-biznes-analitiki-dlyakorporativnyh-informatsionno-analiticheskih-sistem-v-epohu-tsifrovoy (In Russ.)

\section{Conflict-of-interest notification}

We, the authors of this article, bindingly and explicitly declare of the partial and total lack of actual or potential conflict of interest with any other third party whatsoever, which may arise as a result of the publication of this article. This statement relates to the study, data collection and interpretation, writing and preparation of the article, and the decision to submit the manuscript for publication. 